\title{
Taphonomic analysis and sequence stratigraphy of the Albarracinites beds (lower Bajocian, Iberian range, Spain). An example of shallow condensed section
}

\author{
SIXTO RAFAEL FERNÁNDEZ-LÓPEZ ${ }^{1}$
}

\begin{abstract}
Key words. - Taphonomy, Stratigraphic condensation, Palaeobiogeography, Sub-Mediterranean province, Jurassic.
Abstract. - Several ammonite fossil assemblages from Sierra de Albarracín (Teruel, Castilian Branch) contain abundant specimens of the Ovale and Laeviuscula zones (lower Bajocian, Middle Jurassic), including microconchs and macroconchs of the characteristic genus Albarracinites. Over 1500 ammonites from the type horizon of the species $A$. albarraciniensis, in the outcrop of Masada Toyuela, have been studied.

Ammonites are commonly preserved as phosphatized, calcareous, concretionary internal moulds (mean size = $50.5 \mathrm{~mm}$ ) of unflattened shells, partially or completely filled with relatively heterogeneous mudstone to wackestone sediment. Incomplete, fragmented phragmocones with calcitic septa are the dominant remains, generally bearing traces of rounding, incrustation and bioerosion. Taphonomic data, such as the predominant taphonomic populations of type 3 , composed of reelaborated, relatively heterogeneous concretionary internal moulds, isolated concretionary body chambers and hollow ammonites, bearing traces of abrasion, bioerosion and encrusting organisms, are indicative of low rate of sedimentation and occasional high rate of sediment accumulation, due to sedimentary winnowing and bypassing interrupted by storm depositional events, in shallow-water marine environments. The exceptional occurrence of taphonic populations of type 2 belonging to Albarracinites and Hebetoxyites, with dominant shells of pre-adults and absence of juveniles, suggests autochthonous biogenic production of shells by indigenous populations of Sub-Mediterranean taxa at the Iberian platform system.

In the outcrop of Masada Toyuela, the Albarracinites beds correspond to a condensed section, developed in shallow-water, open-marine, carbonate environments of the External Castilian platform. The sharp, irregular base of beds and the normal grading of reworked elements suggest these carbonate deposits were affected by tractive currents, scouring and redeposition. Limestone beds represent storm-related sedimentary events, whereas the local marly intervals represent background-sedimentation time-intervals of winnowing and bypassing on the seafloor. This condensed section is composed of at least four, decimetric or centimetric, expanded-deposit intervals, stacked and showing an overall thinning upward, which constitute a deepening sequence developed during two biochrons. Taphonomic results also corroborate the development of an incipient-deepening phase, which represents the first episode of a deepening half-cycle of third order, in the Albarracín area within the Castilian platform, during the Ovale and Laeviuscula biochrons (early Bajocian).
\end{abstract}

\section{Analyse taphonomique et stratigraphie séquentielle des couches à Albarracinites (Bajocien} inférieur, Chaîne ibérique, Espagne). Un exemple de section condensée d'eaux peu profondes

\begin{abstract}
Mots clés. - Taphonomie, Condensation stratigraphique, Paléobiogéographie, Province subméditerranéenne, Jurassique.
Résumé. - Plusieurs associations d'ammonites de la Sierra de Albarracín (Teruel, Chaîne ibérique castillane) montrent des spécimens remarquablement conservés et abondants, des zones à Ovale et à Laeviuscula (Bajocien inférieur, Jurassique moyen), y compris des microconques et macroconques du genre Albarracinites. Plus de 1500 ammonites de l'horizon type de l'espèce $A$. albarraciniensis, dans la coupe de Masada Toyuela, ont été étudiées.

Les ammonites sont généralement conservées comme moules internes concrétionnels, phosphatés (taille moyenne $=50,5 \mathrm{~mm}$ ), de coquilles non aplaties, partiellement ou entièrement remplis de sédiments calcaires (mudstones - wackestones) relativement hétérogènes. Les fragments de phragmocônes, avec cloisons calcitiques, sont les restes dominants, généralement avec facettes de troncature ou d'arrondissement par abrasion et traces de bioérosion. Les données taphonomiques, tels que la prédominance des populations taphoniques de type 3 , composées de moules internes, phosphatés et réélaborés, de coquilles partiellement ou entièrement remplies de sédiment calcaire relativement hétérogène, et portant des traces d'abrasion, de bioerosion et d'encroûtement, indiquent de faible taux de sédimentation et occasionnellement des taux élevés d'accumulation des sédiments dans des environnements marins relativement peu profonds. La présence exceptionnelle des populations taphoniques de type 2, appartenant à Albarracinites et Hebetoxyites, avec une prédominance de pré-adultes et l'absence d'individus jeunes, suggère une production biogénique de coquilles par des populations autochtones au système de la plate-forme ibérique, et appartenant à des taxons subméditerranéens.
\end{abstract}

1. Departamento de Paleontología (UCM), Facultad de Ciencias Geológicas and Instituto de Geología Económica (CSIC-UCM), c/ José Antonio Novais 2 , E-28040 Madrid, Spain.sixto@geo.ucm.es

Manuscript received on June 26th, 2010; accepted on December 12th, 2010 
Les couches à Albarracinites dans la coupe de Masada Toyuela correspondent à une section condensée, développée dans un milieu marin de plate-forme externe carbonatée, ouvert et peu profond, à faune pélagique et à salinité normale. Les surfaces d'érosion en base de banc et le classement normal des éléments réélaborés suggèrent que ces dépôts carbonatés ont été affectés par l'action de courants de traction, avant redépôt. Les bancs calcaires, bien individualisés lithologiquement entre deux discontinuités stratigraphiques, représentent des dépôts de tempête, alors que les intervalles marneux locaux correspondent à des dépôts mixtes de décantation et de remaniement sur le fond marin, affectés par l'action répétée de la houle. Cette section condensée est constituée d'au moins quatre dépôts de tempête, décimétriques ou centimétriques, témoignant d'un environnement sédimentaire à énergie hydraulique décroissante, et constituent une séquence d'approfondissement engendrée au cours de deux biochrons. Les résultats taphonomiques confirment également le développement d'une phase d'approfondissement, qui représente le premier épisode dans un demi-cycle d'approfondissement de troisième ordre sur le système de plate-forme Ibérique, au cours des biochrons à Ovale et à Laeviuscula du Bajocien inférieur.

\section{INTRODUCTION}

Ammonites of the Ovale and Laeviuscula zones (lower Bajocian, Middle Jurassic) are scarce in the Iberian range mainly due to gaps in the geological record. Nevertheless, several ammonite fossil assemblages from Sierra de Albarracín (Teruel, Castilian Branch) show abundant specimens of these zones, including microconchs and macroconchs of the characteristic genus Albarracinites (fig. 1). The beds containing specimens of this distinct stephanoceratid can be called Albarracinites beds. The outcrop of Masada Toyuela, located on the west side of the Monterde rambla, around $600 \mathrm{~m}$ south from Masia de Toyuela and $6 \mathrm{~km}$ to the north of Albarracín (fig. 2), is the type locality of Albarracinites albarraciniensis FERNÁNDEZLÓPEZ (1985), the type species of this genus. The outcrop is located in the 1: 50.000 topographic sheet of Cella (566, 26-22) [Hernández et al., 1983], coordinates: 40²7' $41^{\prime \prime} \mathrm{N}$, $1^{\circ} 25^{\prime} 58^{\prime \prime} \mathrm{W}$, altitude $1200 \mathrm{~m}$. Over 1500 ammonite specimens from four successive beds, through $1 \mathrm{~m}$ in thickness, of the Ovale and Laeviuscula zones have been collected and studied in the Masada Toyuela area during the last 35 years.
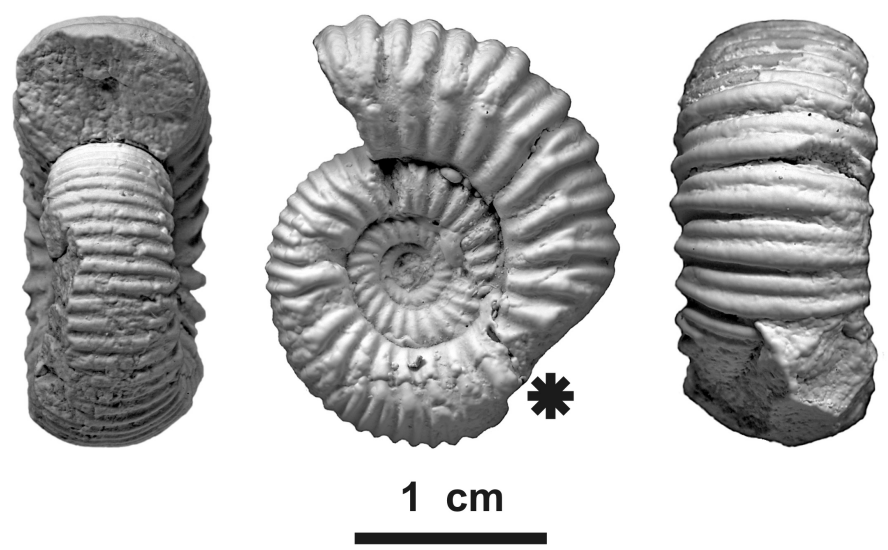

FIG. 1. - Albarracinites albarraciniensis FERNÁNDEZ-LóPEZ. Holotype. Ovale zone, lower Bajocian. Masada Toyuela (Albarracín, Teruel). Coll. SRFL, specimen MT2a/69. The asterisk indicates the beginning of the body chamber. Specimen whitened with magnesium oxide prior to photography. Incomplete microconch with body chamber and phragmocone.

FIG. 1. - Albarracinites albarraciniensis FERNÁNDEZ-LÓPEZ. Holotype. Zone à Ovale, Bajocien inférieur. Masada Toyuela (Albarracín, Teruel).Coll. SRFL, spécimen MT2a/69. L'astérisque indique le début de la loge d'habitation. Le spécimen a été blanchi à la fumée de magnésium. Microconque incomplète avec chambre d'habitation et phragmocône.
Less than 100 of these ammonoids are derived from collections previously studied for biostratigraphic and chronostratigraphic purposes since 1975 [Fernández-López, 1985]. Most specimens and new observations correspond to recent field samplings of this section during 2008 and 2009.

The main purpose of the present work is to interpret from a taphonomic point of view the successive ammonite fossil assemblages at the Ovale and Laeviuscula zones in the Masada Toyuela outcrop, one of the best sections of the Albarracinites beds, in order to test and improve the available data for ammonite palaeobiogeography, biostratigraphic continuity, palaeoenvironmental setting and sequence stratigraphy of this Bajocian time-interval.

\section{GEOLOGICAL SETTING}

The Albarracinites beds correspond to the lower part of $\mathrm{El}$ Pedregal Formation (Chelva Group) [Gómez and FernándezLópez, 2004, 2006]. This lithostratigraphic unit of the External Castilian and Aragonese platforms consists of lime mudstones and wackestones with bioclasts, mainly bivalves (microfilaments), echinoderms and pellets. Zoophycos and Thalassinoides are common. Chert nodules are locally common. Deposits are generally organized into shallowing-upward sequences, coarsening- and thickening-upwards, showing in the uppermost terms hardgrounds with biogenic borings, ferruginous crusts, phosphatic nodules, glauconitic and bioclastic carbonates, as well as reworked fossils. Interbedded horizons of limestones with ferruginous and/or phosphatic ooids are common at the base of this formation. The base of El Pedregal Formation corresponds to the uppermost Murchisonae Zone, although Aalenian and lower Bajocian deposits are usually included in condensed, basal intervals, whereas the top of the formation corresponds to the upper Bajocian Niortense and Garantiana zones.

The Middle Jurassic Iberian carbonate platform system was affected by tensional tectonics and differentially subsiding blocks [Fernández-López and Gómez, 1990a]. Aalenian and lowermost Bajocian deposits are represented by condensed sections on most Iberian platforms. In the NW External Castilian platform, peritidal dolomitic limestones and mudstones, showing microbial laminae and mud-cracks [Fernández-López, 1997a, b], as well as oolitic grainstones, are interbedded in the lower part of the sections. On the Central External Castilian platform or Albarracín sector, however, this unit varies between 60 and $80 \mathrm{~m}$ with upper Aalenian and lower Bajocian deposits represented by expanded sections developed on a downthrown 

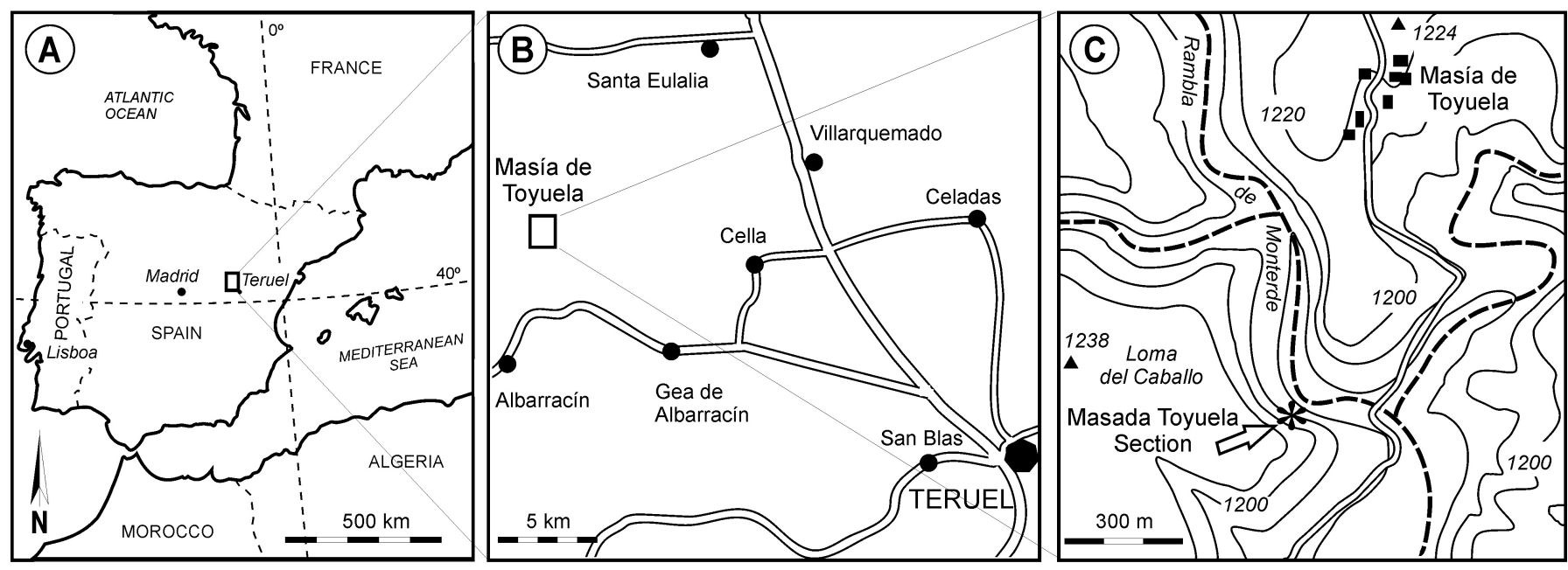

FIG. 2. - Geographic location of the section of Masada Toyuela (Albarracín, Teruel, Spain).

FIG. 2. - Situation géographique de la coupe de Masada Toyuela (Albarracín, Teruel, Espagne).

block, where remains of ammonites, belemnites and benthic organisms, such as bivalves, brachiopods, echinoderms, serpulids, gastropods, bryozoans, sponges and calcareous algae are abundant. Microbial laminae, mud-cracks and karstification surfaces indicate local, occasional emersions [Fernández-López, 1985, 1997a, b; Fernández-López and Gómez, 1990b, 2004]. Therefore, the basal terms of El Pedregal Formation were developed on an outer platform system, dominated by low-energy, open-marine, normal salinity, very shallow to shallow-water environments, occasionally affected by storms. In the Iberian, carbonate, platform system, a Middle Jurassic second-order cycle is recorded as a transgressive-regressive, long-term megasequence, the deepening half-cycle spanning through the Aalenian and Bajocian stages. Third-order depositional sequences within this half-cycle are mainly composed of highstand systems tracts. Small-scale, metric, carbonate shallowing-upward sequences, showing coarsening- and thickening-upward patterns characterize these highstands [Fernández-López, 1997b, 2004; Fernández-López and Gómez, 2004]. This study, however, focuses on certain local lower Bajocian, Ovale and Laeviuscula deposits which are neither organized into a shallowing-upward sequence nor exhibiting a coarsening- and thickening-upward trend.

The Albarracinites beds, generally 0.1 to $2.5 \mathrm{~m}$ thick, from the Ovale and Laeviuscula zones in Albarracín sector, represent a lithologically distinct interval, with concave-up basal surface, intercalated between lime mudstones (fig. 3). The lowest limestone beds either wedge out or increase laterally in thickness over a few hundred of meters, whereas the highest beds display higher lateral continuity. These beds are made up of yellow-brown, wackestone to packstone limestones (containing microfilaments, echinoderms, foraminifera, ostracods and pellets) ranging in thickness from 10 to $40 \mathrm{~cm}$ and interbedded with discontinuous to lenticular bioclastic marls. Limestones may correspond to simple or complex beds, comprising several amalgamated intervals, and show sharp boundaries. Textures and structures of bioturbation are common (Zoophycos, Chondrites and Thalassinoides, in particular) indicating softgrounds to firmgrounds. Macrofossils comprise ammonites, bivalves, crinoid ossicles, irregular echinoids, belemnite guards, gastropods, terebratulid and rhynchonellid brachiopods, nautiloids, irregular echinoids, bryozoans, serpulids, sponges and solitary corals. Several isolated fragmentary bones, of decimetric or centimetric size, have been found in the lowest beds, whereas very few carbonized plant macro-remains occur in the highest beds. Therefore, the Albarracinites beds exhibit a small-scale fining-upward and bedding thinning-upward pattern. Besides Masada Toyuela outcrop, the Albarracinites beds have also been identified in the following sections of the Iberian range [Fernández-López, 1985; Fernández-López et al., 1985; Fernández-López and Aurell, 1988; Fernández-López and Gómez, 1990a, b; Gómez and Fernández-López, 1994; Meléndez et al., 2002]: Barranco La Canaleja (C10-C12), Moscardón (1M10-1M12), Rambla La Gotera (G10-G12), Barranco La Hontanilla (4BH27-4BH33), Gea de Albarracín (G21), Albarracín (19AL25-19AL35), Alustante (1AT5 - 1AT17), Aguatón (AG45), Obón (ON16) and Ricla (RI19-RI24).

\section{MECHANISMS OF TAPHONOMIC ALTERATION AND RESULTS ON AMMONITES}

Taphonomic analysis of the ammonite fossil assemblages from the Albarracinites beds in Masada Toyuela outcrop includes more than 60 preservational features mainly related to biostratinomic and synsedimentary modifications, according to the model of Fernández-López [1997a, b, 2000, 2004, 2008]. The taphonomic analysis is described in terms of preservation state of fossil specimens, taphonic populations and fossil assemblages, specifically the degree and nature of mechanisms of alteration such as: biodegradationdecomposition, incrustation, sedimentary infilling, mineralization, abrasion, bioerosion, dissolution, taphonomic distortion, necrokinesis and fossildiagenetic displacement (reorientation, disarticulation, dispersal, regrouping and remobilization, fig. 4). 
Ammonite remains are dominated by shells, whereas aptychi are very scarce and less than $1 \%$. Ammonite shells are commonly preserved as internal moulds that rarely exceed $300 \mathrm{~mm}$ in diameter (less than $1 \%$, mean size = $50.5 \mathrm{~mm}$; fig 5). Fragmentary body chambers and incomplete phragmocones are abundant, whereas complete peristomed shells are scarce and commonest among the smallest ammonites. Reworked elements (i.e. resedimented or reelaborated elements sensu Fernández-López [1995, 2007]) are dominant. Non-reworked or accumulated elements (showing no evidence of reworking after laying on the seafloor, such as the presence of shell fractures or

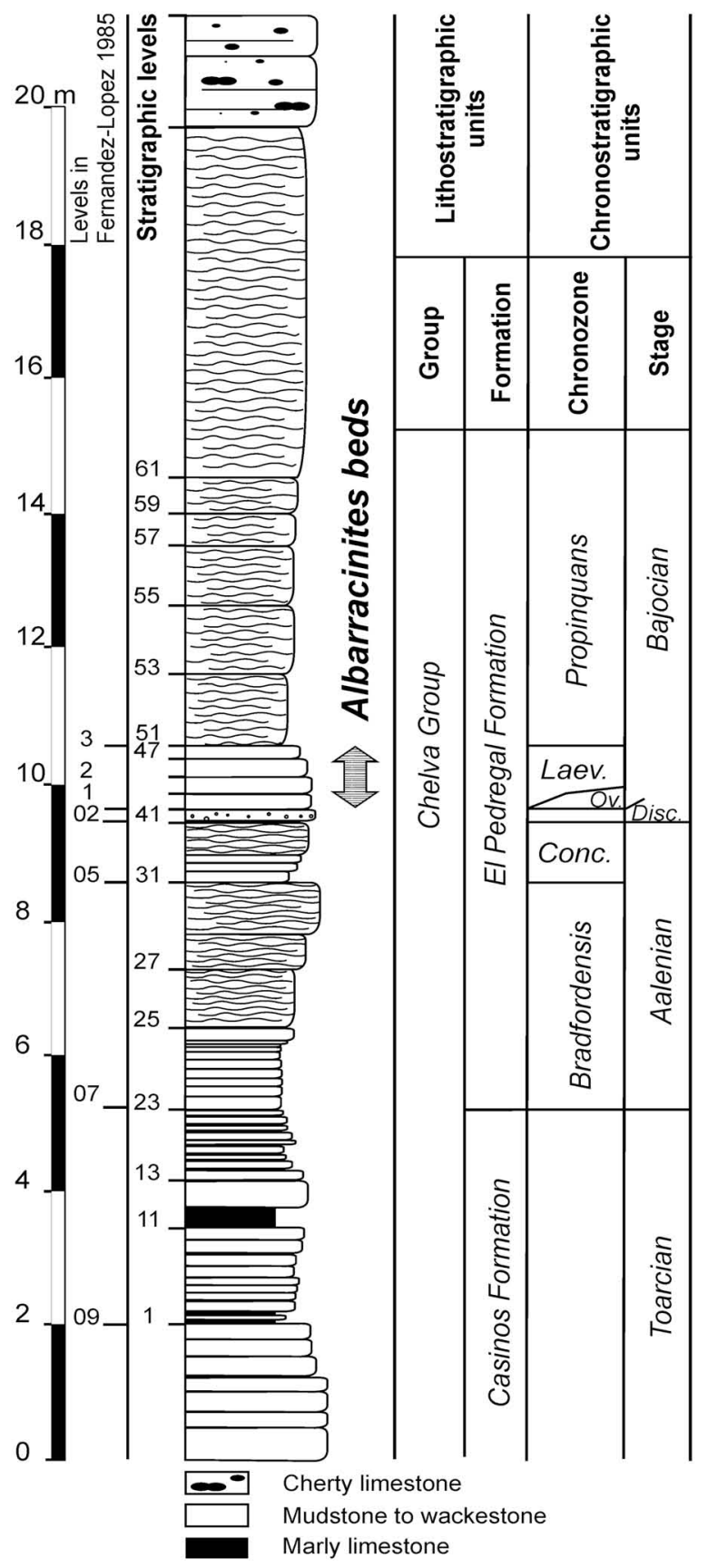

FIG. 3. - Stratigraphic log of the upper Toarcian - lower Bajocian transition in the section of Masada Toyuela, with the position of the Albarracinites beds.

FIG. 3. - Colonne stratigraphique du passage Toarcien supérieur - Bajocien inférieur de la coupe de Masada Toyuela, avec la position des couches à Albarracinites. sedimentary infill in the body chamber) are absent. Reelaborated internal moulds (i.e. exhumed and displaced

\section{BIODEGRADATION}

Body chamber with soft-parts

Body chamber with aptychus

Shell with periostracum

Shell with articulated siphuncular tube

\section{NCRUSTATION}

Shell with intrathalamic encrusting

Specimen with extrathalamic encrusting

Specimen with stromatolitic laminae

Ammonite half-lump

\section{SEDIMENTARY INFILL}

Sedimentary intemal mould of bodychamber and phragmocone Sedimentary intemal mould of bodychamber

Sedimentary intemal mould of phragmocone

Body chamber without aboral sedimentary infill

Fragmocone with incomplete sedimentary infill (hollow ammonites) Heterogeneous sedimentary infill of shell

Micritic intemal mould

Oolitic internal mould

Glauconitic intemal mould

Siliciclastic pseudomorphosis of shell

Sedimentary intemal mould with draft-filling spiral channel

SYNSEDIMENTARY MINERALIZATION

Calcareous intemal mould

Phosphatic intemal mould

Silicified internal mould

Pyritic intermal mould
Ammonite half-concretion

Ammonite half-concretion
Calcitic pseudomorphosis of shell

\section{ABRASION}

Internal mould with truncation facet

Internal mould with roll facet

Intermal mould with ellipsoidal facet

Intemal mould with annular furrow

BIOTURBATION AND BIOEROSION

Sedimentary intemal mould with bioturbation structures

Internal mould with biogenic borings

SYNSEDIMENTARY DISSOLUTION

Periostracum without either septa or wall

Shell without septa (hollow phragmocone)

Concretionary intemal mould without septa

Concretionary internal mould without inner whorls

TAPHONOMIC DISTORTION

Peristomed ammonites

Complete shell (with body chamber and phragmocone)

Incomplete shell of bodychamber

incomplete shell of bodychamber

Incomplete shell of phragm

Shell with opened fracture

Mould with discontinuous deformation by compaction

Mould with continuous deformation by compaction

REORIENTATION

Shell with azimuthal reorientation
Internal mould with azimuthal reorientation

Vertical shell

Vertical concretionary intermal mould

DISARTICULATION

Disarticulated aptichus

Disarticulated siphuncular tube

Disarticulated intermal mould

DISPERSAL

Taphonic population of type 1

Taphonic population of type 2

Taphonic population of type 3

REGROUPING

Encased shells

Imbricated shells

Imbricated intemal moulds

Alignment of concretionary intemal moulds

Ammonite packing

Ammonite stratigraphical-persistence

REMOVAL - REMOBILIZATION

Accumulated element

Resedimented element

Reelaborated element
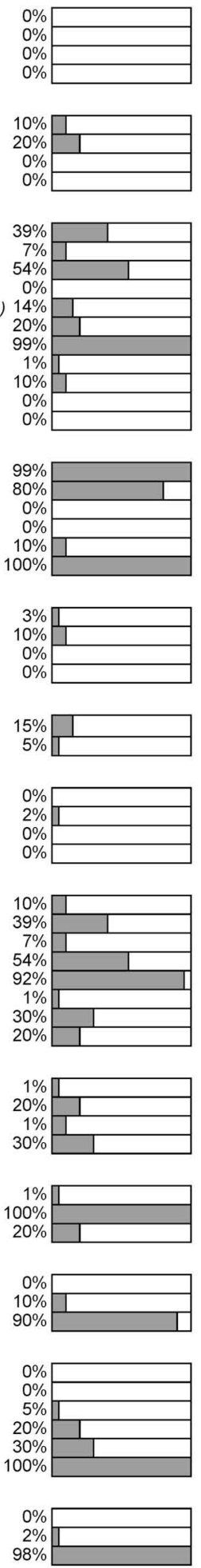

FIG. 4. - Taphonomic features of the ammonites of the Albarracinites beds in Masada Toyuela section.

FIG. 4. - Caractéristiques taphonomiques des ammonites des couches à Albarracinites sur la coupe de Masada Toyuela. 


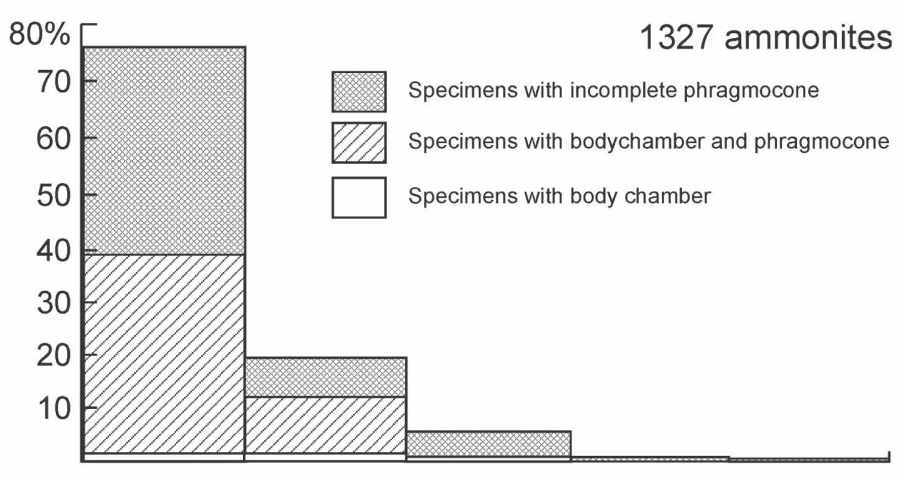

Dmax. $=300 \mathrm{~mm}$

FIG. 5. - Size-frequency distribution of the ammonites of the Albarracinites beds in the section of Masada Toyuela, to show the proportion of body chambers, complete shells and incomplete phragmocones.

Fig. 5. - Histogramme de variabilité de taille entre les ammonites des couches à Albarracinites de la coupe de Masada Toyuela, montrant la proportion des chambres d'habitation, coquilles complètes and phragmocônes incomplets.

before their final burial) are dominant (up to 98\%), showing distinctive white or reddish colour, structural discontinuity with the sedimentary matrix, and original shape lacking extensive deformation by compaction (figs. 6-8). In contrast, resedimented shells (i.e. displaced on the seafloor before their burial) can be locally common in the highest beds, displaying textural and structural continuity between the sedimentary infill and the matrix, and showing compression by diagenetic compaction. Note that the terms reelaborated, reworked and remanié or derived are not synonyms in a taphonomic context. The French word "remanié" meaning "reworked" or "rehandled", applied in geology to fragments or entities derived from older materials, in particular to fossils removed from or washed out of an older bed and redeposited in a new one, is a stratigraphic term [cf. Jackson, 1997]. Reworked or derived fossils, meaning fossils from rocks of one age that have been eroded, transported, and redeposited in sediments of a younger age, also is a stratigraphic term [cf. Jackson, 1997]. In contrast, the taphonomic terms remobilized or reworked, as antonymous of accumulated and meaning resedimented or reelaborated, allows recognizing the relationships between the fossils and their sedimentary matrix even in the case of fossiliferous lithoclasts. From a stratigraphic point of view every fossil included in a lithoclast is a reworked or derived fossil, whereas from a taphonomic point of view it can be identified as an accumulated, resedimented or reelaborated fossil in relation to the sedimentary matrix or the enclosing rock [Fernández-López, 1991, 1995, 2007].

Biostratinomic processes of biodegradation-decomposition in oxic conditions were intense and ammonite shells usually lost the soft parts, aptychus and periostracum before burial. Aptychi have hardly ever been found within the

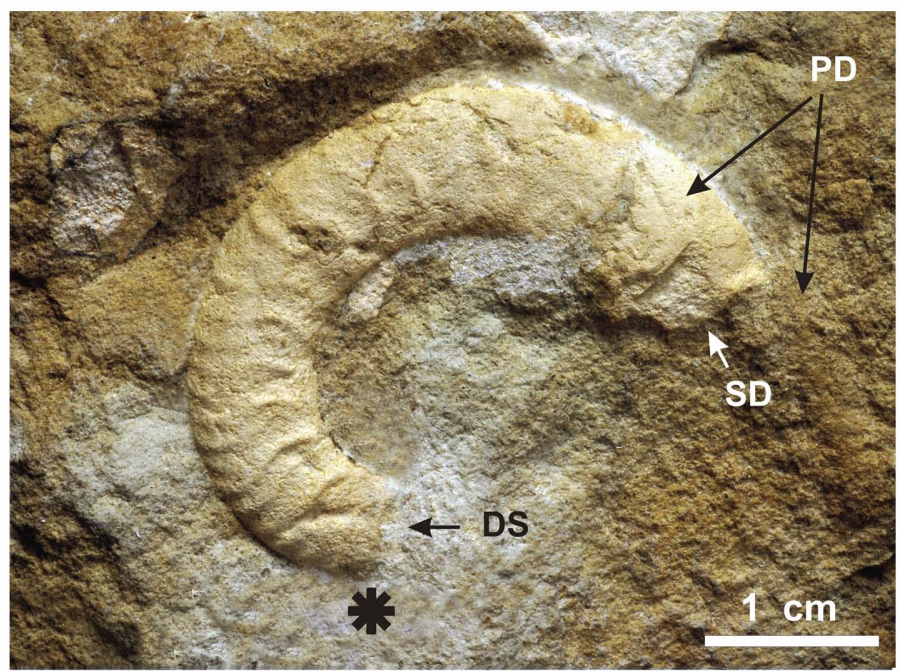

Fig. 7. - "Fontannesia" sp., microconch. Laeviuscula Zone, lower Bajocian, Masada Toyuela (Albarracín, Teruel). Coll. SRFL, specimen MT2/700. The asterisk indicates the beginning of the body chamber. Reelaborated, concretionary internal mould of an isolated body chamber showing: (PD) petrographic difference between the phosphatic sedimentary infill and the enclosing sedimentary rock, (SD) structural discontinuity between the sedimentary infill and the sedimentary matrix, and (DS) disarticulation surface developed along the boundary between sedimentary infills of body chamber and phragmocone, after dissolution of the last septum and the wall, and before the final burial.

Fig. 7. - "Fontannesia" sp., microconque. Zone à Laeviuscula, Bajocien inférieur, Masada Toyuela (Albarracín, Teruel). Coll. SRFL, spécimen MT2/700. L'astérisque indique le début de la loge d'habitation. Moule interne concrétionnel, réélaboré, de la chambre d'habitation montrant: $(P D)$ différence pétrographique entre le remplissage sédimentaire et la roche, $(S D)$ discontinuité structurale avec la matrice sédimentaire, et (DS) surface de désarticulation entre la chambre d'habitation et le phragmocône, développée à la limite des remplissages sédimentaires des chambres voisines, après la dissolution de la dernière cloison du phragmocône et de la muraille, et avant l'enfouissement final. 


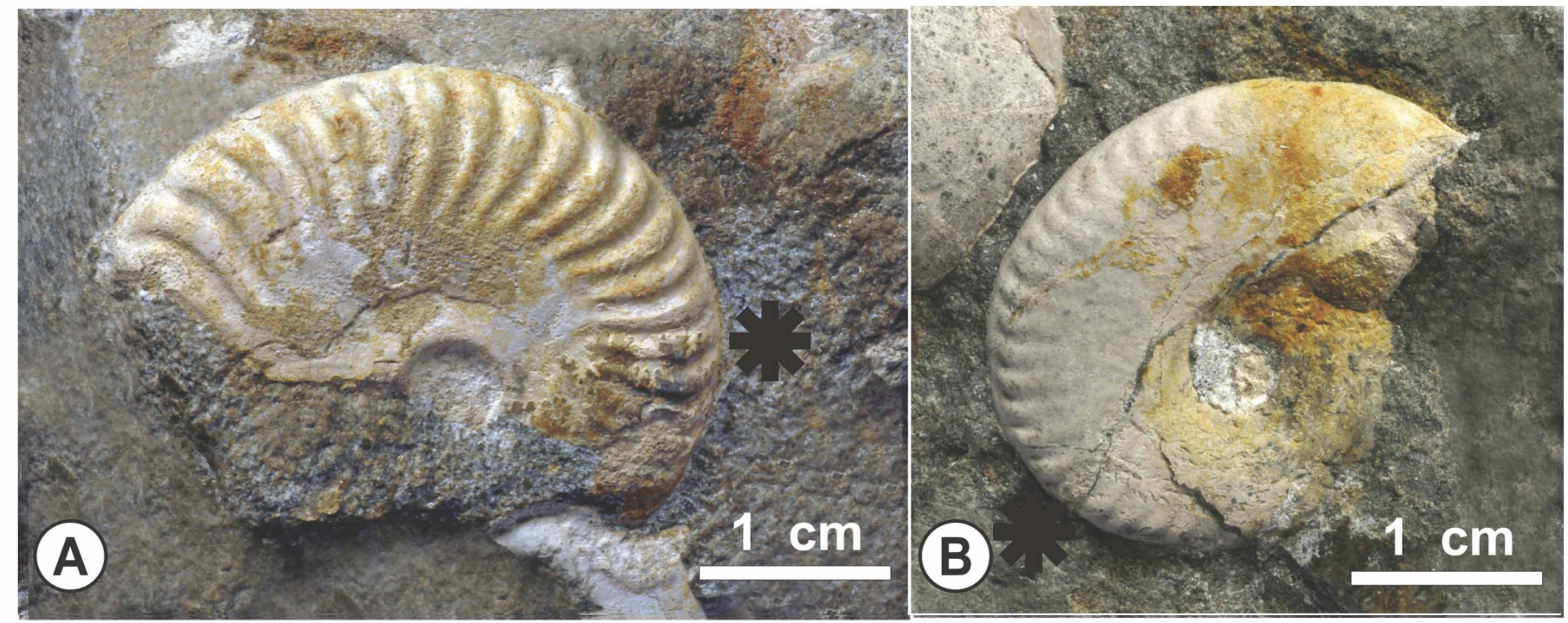

FIG. 8. - Reelaborated internal moulds of Hebetoxyites sp. Laeviuscula Zone, lower Bajocian. Masada Toyuela (Albarracín, Teruel). Coll. SRFL. The asterisk indicates the beginning of the body chamber. A) macroconch, MT2/301, incomplete shell with body chamber and phragmocone. B) microconch, MT2d/366, complete shell with body chamber and phragmocone.

Fig. 8. - Moules internes concrétionnels, réélaborés, de Hebetoxyites sp. Zone à Laeviuscula, Bajocien inférieur. Masada Toyuela (Albarracín, Teruel). Coll. SRFL. L'astérisque indique le début de la loge d'habitation. A) macroconque, MT2/301, coquille incomplète avec chambre d'habitation et phragmocône. B) microconque, MT2d/306, coquille complète avec chambre d'habitation et phragmocône.

ammonite shells. Also siphuncular tubes are generally disarticulated.

Shells bearing signs of intrathalamic and/or extrathalamic encrusting organisms (such as serpulids, bryozoans, oysters or crinoids) [Tintant, 1984] are common. Biogenic borings and remains of epilithic organisms commonly occur on the largest-size, reelaborated, concretionary internal moulds. However, dense encrusting, pisolitic or oncolitic ammonoids, ammonite half-lumps [FernándezLópez et al., 2002] or microbial stromatolitic laminae [Olóriz et al., 2004] have not been observed.

Internal moulds of shells completely filled with relatively heterogeneous sediments are common, indicating low rate of sedimentation. However, shells with incomplete sedimentary infill (hollow ammonites) are common among the smallest ammonites (14\%) and isolated concretionary internal moulds of body chambers are relatively common (surpassing 7\%), indicating low rate of sedimentation and occasional high rate of sediment accumulation. Internal moulds showing asymmetrically preserved flanks, varying in clay content, are commonest in the highest beds. Internal moulds with a local infill channel on the ventral region [Seilacher, 1971; Fernández-López, 2008] are very scarce. Body chambers without aboral sedimentary infill or siliciclastic pseudomorphosis of shells are absent. This abundance of relatively heterogeneous concretionary internal moulds, associated with isolated concretionary body chambers and hollow ammonites, are indicative of low rate of sedimentation and occasional high rate of sediment accumulation during biostratinomic processes [FernándezLópez et al., 2002; Fernández-López, 2008].

Processes of synsedimentary mineralization were intense and indicative of low rate of sedimentation. Ammonites are generally preserved as calcareous and phosphatized, concretionary, internal moulds of shells
(80-90\%). Glauconitic internal moulds are locally common (10\%). Calcareous half-concretions and asymmetrically compressed concretions of ammonite shells occur $(10 \%)$. Pyritic or silicified concretionary internal moulds are absent.

Traces of abrasion on shells and internal moulds are abundant in the lowest levels. Truncation facets on a flank occur preferentially among the largest-size ammonites, whereas abrasion roll facets preferentially developed on the most prominent portions of concretionary internal moulds are relatively common among the smallest specimens. The occurrence of worn surfaces of this type is due to the higher mechanical stability and the higher probability of abrasion of the largest specimens during the processes of synsedimentary exhumation by sedimentary winnowing. Internal moulds with abrasion ellipsoidal facets or annular furrows are virtually absent [Fernández-López and Meléndez, 1995].

Concretionary internal moulds of phragmocones with calcitic septa are the dominant fossils. Hollow phragmocones [i.e. shells without septa; sensu Seilacher et al., 1976; Maeda and Seilacher, 1996] are scarce (2\%), usually compressed by sedimentary loading during early diagenesis, and preferentially located in the highest stratigraphic levels. Aragonitic walls of the shells were dissolved during later diagenetic processes than septa. Septa of hollow phragmocones may have disappeared by early dissolution, while the walls of the shells still persisted, giving rise to compressed elements showing discontinuous deformation of the wall by gravitational compaction [Hagdorn and Mundlos, 1983; Fernández-López, 1997a]. Concretionary internal moulds without septa [Fernández-López, 2000], indicative of synsedimentary dissolution of septa, are absent. No signs of biostratinomic or synsedimentary dissolution of the aragonitic remains have been recognized. Aragonitic shells were dissolved during later diagenetic processes. 
Moldic porosity resulting from dissolution processes of shells and septa, and millimetric cracks of the sedimentary matrix due to lithostatic decompression, were partially filled by recent spar cement.

Ammonoid assemblages show a high proportion of incomplete phragmocones (up to 66\%) and scarce complete shells with peristome (10\%; fig. 4). Fragmented specimens of resedimented shells are present $(2 \%)$, but generally bearing no signs of rounding, incrustation or bioerosion, due to low turbulence near the water/sediment interface. Reelaborated internal moulds are abundant (up to $98 \%$ ), often showing reverse geopetal sedimentary infill and disarticulation surfaces with sharp margins along dissolved septa. Ammonoid shells occur in both limestone and marly intervals, but unflattened concretionary internal moulds are dominant in limestone beds, whereas crushed shells occur in marly intervals. Discontinuous $(30 \%)$ or continuous $(20 \%)$, compressed, concretionary internal moulds, resulting from diagenetic compaction, occur preferentially in the highest levels. Discontinuous deformations, with sign of breaking of the shell and compression by diagenetic compaction, or continuous deformations on the flanks of internal moulds commonly are asymmetrically arranged, as the degree of deformation is proportional to the clay content of sedimentary infill.

Stratigraphic data on high abundance and concentration of ammonoids are also relevant for taphonomic analysis [Tomasovych and Schlögl, 2008]. Packing density and stratigraphic persistence of ammonites display very high and maximum values $(30 \%$ and $100 \%$, respectively). Ammonites commonly appear scattered in the deposits, but locally show patterns of imbricated (arranged so as to overlap each other) or encased (enclosed within another one) regrouping and normal grading. Concretionary internal moulds can show vertical attitude, especially in lower terms of the beds, but they are horizontally reoriented and form alignments in the marly intervals.

Taphonic populations of type 3 are dominant, whereas types 2 or 1 are very scarce and virtually absent, respectively [Fernández-López and Mouterde, 1994, 1997; Fernández-López, 1995; Fernández-López and Meléndez, 1996; D’Arpa and Meléndez, 2004; Meléndez et al., 2009]. Taphonic populations of type 3 show uni- or polymodal and asymmetric distribution of size frequencies, with negative skew and predominant adult shells, juvenile shells being virtually absent. Taphonic populations of type 1, dominated by juvenile shells and indicative of eudemic taxa and autochthonous biogenic production, have not been recognized [Fernández-López and Gómez, 2004; FernándezLópez and Meléndez, 2004; Reboulet et al., 2003, 2005]. However, adult microconchs are quite common in some taxonomic groups (Maceratites, Pelekodites and Otoites). Most of these lower Bajocian ammonite shells represent ademic organisms and are interpreted as allochthonous elements arrived at their present location by necroplanktic drift from northern, more open marine or oceanic areas. In contrast, Albarracinites (fig. 9) and Hebetoxyites (fig. 10) are represented by taphonic populations of type-2 (i.e. composed of mono- or polyspecific shells, showing unimodal and normal distribution of size-frequencies with dominant pre-adults and absence of juveniles; microconchs represent a low proportion). The occurrence of taphonic populations of type 2 , showing no trace of sorting by necroplanktic drift or transport, is indicative of autochthonous biogenic production of shells.

The degree of remobilization, reworking or removal (i.e. the ratio of reelaborated or resedimented elements to total recorded elements) reaches $100 \%$ in the four successive beds. The degree of taphonomic heritage (i.e. the ratio of reelaborated elements to total recorded elements) [Fernández-López and Meléndez, 1995; Fernández-López and Mouterde, 1997] decreases upwards, reaching a value below $50 \%$ in the highest stratigraphic interval. The degree of taphonomic condensation (i.e. mixing of fossils of different chronostratigraphic units) reaches the highest values in the lowest beds. Ammonoid mixed-assemblages composed of specimens representing several biohorizons in a single bed have been identified in the lowest levels.
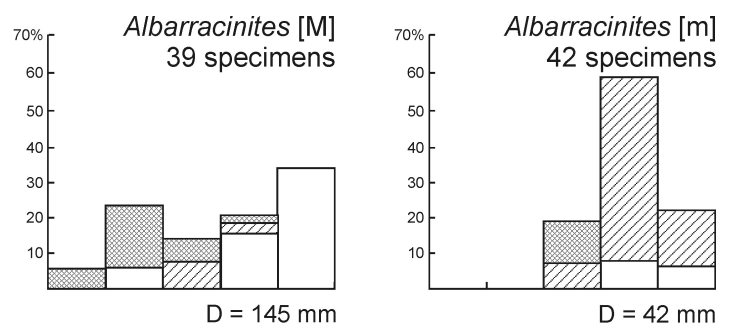

Specimens with incomplete phragmocone Specimens with bodychamber and phragmocone Specimens with body chamber

FIG. 9. - Size-frequency distributions of macroconchs and microconchs of Albarracinites, in the section of Masada Toyuela, indicating the proportion of body chambers, complete shells and incomplete phragmocones.

FIG. 9. - Comparaison de la variabilité de taille par histogramme entre les formes macroconques et les microconques d'Albarracinites, de la coupe de Masada Toyuela, avec la proportion des chambres d'habitation, coquilles complètes and phragmocônes incomplets.
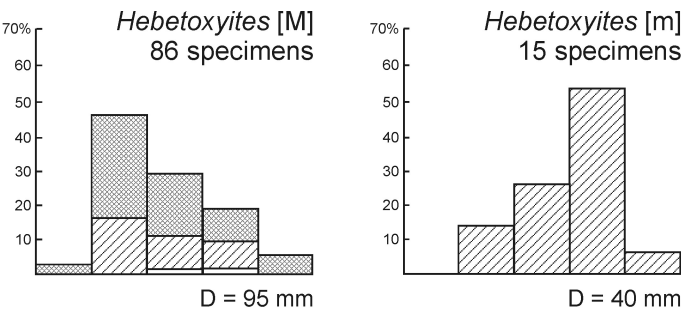

Specimens with incomplete phragmocone Specimens with bodychamber and phragmocone Specimens with body chamber

FIG. 10. - Size-frequency distributions of macroconchs and microconchs of Hebetoxyites, in Masada Toyuela section, indicating the proportion of body chambers, complete shells and incomplete phragmocones.

FIG. 10. - Comparaison de la variabilité de taille par histogramme entre les formes macroconques et les microconques de Hebetoxyites, de la coupe de Masada Toyuela, avec la proportion des chambres d'habitation, coquilles complètes and phragmocônes incomplets. 


\section{PALAEOENVIRONMENTAL SETTING AND SEQUENCE STRATIGRAPHY}

Taphonomic analysis of ammonoid fossil assemblages and taphofacies are of stratigraphic interest since they provide an independent test of the palaeoenvironmental cycles inferred in sequence stratigraphy [Brett and Baird, 1986; Fernández-López, 1991, 1995, 1997a, b, 2000, 2004, 2008; Fürsich and Oschmann, 1993; Aurell et al., 1994; Gómez and Fernández-López, 1994; Pavia, 1994; Brett, 1995, 1998; Martire and Pavia, 1996; Pavia and Martire, 1997, 2009; Monaco, 1999, 2000; Caracuel et al., 2000; Monaco and Giannetti, 2001, 2002; Courville and Collin, 2002; Olóriz et al., 2002, 2004, 2008; Maeda et al., 2003, 2010; Wani, 2003; Bello, 2005; Meléndez et al., 2005, 2007; Metodiev and Koleva-Rekalova, 2005; Reolid, 2005; Reolid et al., 2005, 2010; García-Frank, 2006; Ramajo, 2006; Fürsich et al., 2007; Paul et al., 2008; Coimbra et al., 2009; Kietzmann and Palma, 2009].

Taphonomic data from Masada Toyuela section, such as predominance of taphonic populations of type 3, composed of reelaborated, heterogeneous concretionary internal moulds, isolated concretionary body chambers and hollow ammonites, bearing traces of abrasion, bioerosion and encrusting organisms, are indicative of low rate of sedimentation and occasional high rate of sediment accumulation, due to sedimentary winnowing and bypassing in shallow-water, marine environments [incipient-deepening taphorecords in Fernández-López, 1997b, 2004]. In contrast, due to sedimentary starving in deep-water environments, condensed associations included in condensed deposits developed during transgressive trends are characterized by the occurrence of taphonic population of type 1 (dominated by juvenile shells), composed of reelaborated, non-hollow ammonites and homogeneous concretionary internal moulds, bearing no signs of abrasion, bioerosion or encrusting organisms (such as serpulids, bryozoans or oysters) [advanced-deepening taphorecords in Fernández-López, 1997b, 2004; Fernández-López et al., 2002; Fernández-López and Meléndez, 2004; Fernández-López, 2007].

The four, decimetric to centimetric, elementary, limestone-marl cycles commonly differentiated in the Albarracinites beds are stacked tempestites, which show an overall fining and thinning upward gradient. The sharp, irregular base of beds and the normal grading of reworked elements suggest these carbonate deposits were affected by tractive currents, scouring and redeposition. Carbonate tempestites represent expanded sediments generated under brief episodes of high rate of sediment accumulation, whereas marly intervals correspond to condensed stratigraphic intervals developed under lasting episodes of low sedimentation rate. The limestone beds represent storm-related sedimentary events, whereas the local marly intervals represent background-sedimentation time-intervals of winnowing and bypassing on the sea-bottom.

The Albarracinites beds at the outcrop of Masada Toyuela constitute a condensed sequence, developed in a shallow, open-marine, carbonate platform (the External Castilian Platform). Time intervals of lower rate of sedimentation, associated with sedimentary winnowing and bypassing during progressive infilling towards the top of a transgressive systems tract, favoured higher degrees of biodegradation, encrusting, sedimentary infill, synsedimentary mineralization,

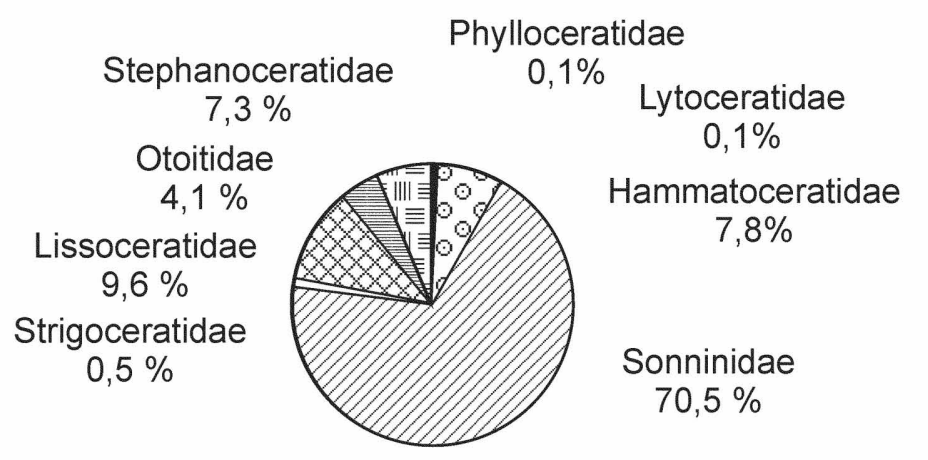

Class Cephalopoda Cuvier, 1798

Specimens:

Subclass Ammonoidea Zittel, 1884

1327

Order Phyllocerida Schindewolf, 1923

Family Phylloceratidae Zittel, 1884 Holcophylloceras

Order Lytocerida Hyatt, 1889

Family Lytoceratidae Neumayr, 1875 Lytoceras

Order Ammonitida Zittel, 1884

Suborder Psilocerina Schidewolf, 1923

Superfamily Hammatoceratoidea Schindewolf, 1964 Family Hammatoceratidae Buckman, 1867 Fissilobiceras $[\mathrm{M}+\mathrm{m}]$

Family Sonniniidae Buckman, 1892 Sonninia [M]

Papilliceras [M]

Pseudoshirbuirnia [M]

Euhoploceras [M]

Sonninites [M]

Pelekodites [m]

Witchellia $[\mathrm{M}+\mathrm{m}]$

Maceratites [m]

Fontannesia $[\mathrm{M}+\mathrm{m}]$

Family Strigoceratidae Buckman, 1924 Strigoceras [M] Cadomoceras [m]

Suborder Haplocerina Besnosov \& Michailova, 1983

Superfamily Haploceratoidea Zittel, 1884

Family Lissoceratidae Douvillé, 1885 Lissoceras $[\mathrm{M}+\mathrm{m}]$

Toxamblyites $[\mathrm{M}+\mathrm{m}]$

Bradfordia $[\mathrm{M}+\mathrm{m}]$

Amblyoxyites [M]

Hebetoxyites $[86 \mathrm{M}+15 \mathrm{~m}]$

Her

Superfamily Stephanoceratoidea Neumayr, 1875

Family Otoitidae Mascke, 1907

Emileia [M]

Otoites [m]

Emileites [M]

Frogdenites [M]

Docidoceras [M]

Trilobiticeras [m]

Family Stephanoceratidae Neumayr, 1875 Skirroceras [M]

Mollistephanus [M]

Albarracinites $[42 \mathrm{~m}+39 \mathrm{M}]$

Riccardiceras [M]

FIG. 11. - Relative abundance of different ammonite families in the Albar racinites beds in the section of Masada Toyuela. Orders of the subclass Ammonoidea and suborders of the order Ammonitida according to Shevyrev [2006]. The family Hammatoceratidae includes the genus Fissilobiceras, according to Chandler et al. [2006].

FIG. 11. - Diagramme circulaire de répartition des pourcentages des familles d'ammonites dans les couches à Albarracinites de la coupe de Masada Toyuela. Ordres and subordres d'après Shevyrev [2006]. La famille Hammatoceratidae inclut le genre Fissilobiceras, d'après Chandler et al. [2006]. 
reworking and regrouping of ammonoid shells, and enhanced the preservation potential of the ammonite shells. This condensed section is composed of at least four, decimetric or centimetric, expanded-deposit intervals, stacked one upon the other with an overall thinning upward pattern, which constitute a deepening sequence developed during two biochrons. Taphonomic analysis of successive ammonite fossil assemblages and taphofacies corroborate the development of an incipient-deepening phase, which characterizes the first episode within a deepening half-cycle of third and second order cycles, in the Albarracín area of Castilian platform during the Ovale and Laeviuscula biochrons (early Bajocian).

\section{PALAEOBIOGEOGRAPHICAL IMPLICATIONS}

The general pattern of the early Bajocian ammonoid assemblages on the External Castilian platform was a mixing of elements representatives of NW European and Mediterranean provinces, associated with some Sub-Mediterranean ones [Fernández-López, 1985; Fernández-López and Gómez, 1990b, 2004]. In the NW and Central sectors of the External Castilian platform, the successive ammonoid assemblages were mostly the result of regional necrokinesis from septentrional and meridional epeiric seas and oceans. Early Bajocian submarine environments were inadequate for the ontogenic development of the ammonites, although some stenotopic organisms were able to ephemerally proliferate in these sectors. Ammonite-shell supply took place preferentially from more septentrional epicontinental seas, although the proportion of mesogean elements increased during the early Bajocian.

At the outcrop of Masada Toyuela, in particular, the total number of the ammonites studied from the Albarracinites beds is up 1500 (fig. 11). Families Sonniniidae and Hammatoceratidae are dominant $(70.5$ and $7.8 \%$, respectively), the genera Witchellia [M] and Maceratites [m] being the most common. Lissoceratidae and Stephanoceratidae are scarce (9.6 and $7.3 \%)$, but Hebetoxyites
$[\mathrm{M}+\mathrm{m}]$ and Albarracinites $[\mathrm{M}+\mathrm{m}]$ are well represented. Otoitidae and Strigoceratidae are very scarce (4.1 and $0.5 \%)$. Phylloceratidae and Lytoceratidae are extremely scarce $(0.1 \%)$. Mediterranean palaeobiogeographic groups characteristically refer to Phyllocerida and Lytocerida, whereas some genera of Sonniniidae such as Witchellia [M] and Maceratites $[\mathrm{m}]$ are characteristic taxa of the NW European Province. Most of these early Bajocian ammonoids of the Castilian platform, dominated by adult individuals, were the result of regional necrokinesis and/or local immigration, without evidences of colonization. Albarracinites and Hebetoxyites, however, are represented by pre-adult shells and show no trace of sorting by necroplanktic drift or transport, which is indicative of autochthonous biogenic production of shells. Therefore, they can correspond to indigenous populations of the Iberian platform system including Sub-Mediterranean species.

\section{CONCLUSIONS}

The Albarracinites beds at the outcrop of Masada Toyuela may be considered as an example of condensed section, composed of expanded deposits and containing high concentrations of ammonites, developed in shallow-water, open-marine, carbonate environments of outer platform during an incipient-deepening phase, which represents the first episode of a deepening half-cycle of third order.

Ammonite taphonomy is a useful tool in sequence stratigraphy of carbonate epicontinental platforms to discern between condensed sections formed by 1) expanded deposits of shallow environments and 2) condensed deposits of deep environments.

Acknowledgments. - I would like to thank P.-Y. Collin (Associate Editor), two anonymous referees and O. Lacombe (Rédacteur en Chef du Bulletin de la Société Géologique de France) for their constructive comments and suggestions on the manuscript. This work was supported by the research project CGL2008-01273 (MICINN) and grants from the Dirección General de Patrimonio Cultural del Gobierno de Aragón (Nº. Exp. 040/08-2009) and the Fundación Conjunto Paleontológico de Teruel-Dinópolis (2008-2009).

SGF associate editor: P.-Y. Collin

\section{References}

Aurell M., Fernández-López S. \& Meléndez G. (1994). - The MiddleUpper Jurassic oolitic ironstone level in the Iberian range (Spain): eustatic implications. - Geobios, M.S. 17, 549-561.

Bello J. (2005). - El Oxfordiense en el sector nororiental de la Cordillera Ibérica: bioestratigrafía y paleontología (Ammonoidea). 416 p. Tesis doctoral, Univ. Zaragoza, 2005.

BRETT C.E. (1995). - Sequence stratigraphy, biostratigraphy, and taphonomy in shallow marine environments. - Palaios, 10, 597-616.

BRETT C.E. (1998). - Sequence stratigraphy, paleoecology, and evolution: biotic clues and responses to sea-level fluctuations. - Palaios, 13, 241-262.

BRETT C.E. \& BAIRD G.C. (1986). - Comparative taphonomy: A key to paleoenvironmental interpretation based on fossil preservation. Palaios, 1, 207-227.

Caracuel J.E., Monaco P. \& Olóriz F. (2000). - Taphonomic tools to evaluate sedimentation rates and stratigraphic completeness in Rosso Ammonitico facies (Epioceanic Tethyan Jurassic). - Riv. Ital. Paleontol. Stratigr., 106, 353-368.
Chandler R.B., Callomon J.H., King A., Jeffrey K., Varah M. \& Bentley A. (2006). - The stratigraphy of the Inferior Oolite at South Main Road quarry, Dundry, Avon. - Proc. Geol. Assoc., 117, 345-375.

Coimbra R., Immenhauser A. \& Olóriz F. (2009). - Matrix micrite $\mathrm{d}^{13} \mathrm{C}$ and $\mathrm{d}^{18} \mathrm{O}$ reveals synsedimentary marine lithification in Upper Jurassic Ammonitico Rosso limestones (Betic Cordillera, SE Spain). - Sediment. Geol., 219, 332-348.

Courville P. \& Collin P.Y. (2002). - Taphonomic sequences - A new tool for sequence stratigraphy. - Geology, 30, 511-514.

D'ARPA C. \& MELÉndez G. (2004). - Oxfordian biostratigraphy and ammonite associations from west Sicily: biostratigraphic succession of genus Gregoriceras and correlation with Tethyan perisphinctid scale. - Riv. Ital. Paleontol. Stratigr.,110, 255-267.

FERnÁndeZ-LóPEZ S. (1985). - El Bajociense en la Cordillera Ibérica. 850 p. - Thesis doctoral, Univ. Complutense Madrid.

FERNÁNDEZ-LóPEZ S. (1991). - Taphonomic concepts for a theoretical biochronology. - Rev. Esp. Paleont., 6, 37-49. 
FERNÁNDEZ-LóPEZ S. (1995). - Taphonomie et interprétation des paléoenvironnements. In: M. GAYET \& B. Courtinat, Eds., First European Palaeontological Congress, Lyon 1993. - Geobios, M.S. 18 $137-154$

FERNÁNDEZ-LóPEZ S. (1997a). - Ammonites, clinos tafonómicos y ambientes sedimentarios. - Rev. Esp. Paleont., 12, 102-128.

FERNÁNDEZ-LóPEZ S. (1997b). - Ammonites, taphonomic cycles and stratigraphic cycles in carbonate epicontinental platforms. - Cuad. Geol. Ibérica, 23, 95-136.

FERNÁNDEZ-LóPEZ S.R. (2000). - Ammonite taphocycles in carbonate epicontinental platforms. - GeoResearch Forum, 6, 293-300

FERNÁNDEZ-LóPEZ S.R. (2004). - Diagnóstico paleontológico de ciclos paleoambientales en plataformas epicontinentales carbonáticas. Ejemplos del Jurásico Medio de la Cordillera Ibérica. In: E. Baquedano \& S. Rubio Jara, Eds., Miscelánea en homenaje a Emiliano Aguirre, Volumen II, Paleontología. - Zona Arqueológica, 4, 181-200.

FERNÁNDEZ-LóPEZ S.R. (2007). - Ammonoid taphonomy, palaeoenvironments and sequence stratigraphy at the Bajocian/Bathonian boundary on the Bas Auran area (Subalpine Basin, SE France). Lethaia, 40, 377-391.

FERNÁNDEZ-LóPEZ S.R. (2008). - Distinction between fill channels and abrasion furrows on ammonoid internal moulds. - Geobios, $\mathbf{4 1}$ $5-13$.

Fernández-López S. \& Aurell M. (1988). - El Bajociense y Bathoniense de Ricla (Zaragoza). Características bioestratigráficas y sedimentológicas. - Ciencias de la Tierra, Geología, 11, 251-264.

FERnÁNDEZ-López S. \& Gómez J.J. (1990a). - Facies aalenienses y bajocienses, con evidencias de emersión y carstificación, en el sector central de la Cuenca Ibérica. Implicaciones paleogeográficas. Cuad. Geol. Ibérica, 14, 67-111.

FERNÁNDEZ-LóPEZ S. \& GómEZ J.J. (1990b). - Evolution tectono-sédimentaire et genèse des associations d'ammonites dans le secteur central du Bassin ibérique (Espagne) pendant l'Aalénien. - Cah. Univ. Catho. Lyon, sér. sci., 4, 39-52.

Fernández-LóPEZ S. \& Gómez J.J. (2004). - The Middle Jurassic eastern margin of the Iberian platform system (eastern Spain). Palaeogeography and biodispersal routes of ammonoids. - Riv. Ital. Pa leontol. Stratigr., 110, 151-162.

FERnÁndeZ-López S. \& MelÉndez G. (1995). - Taphonomic gradients in Middle Jurassic ammonites of the Iberian range (Spain). In: M Gayet \& B. Courtinat, Eds., First European Palaeontological Congress, Lyon 1993. - Geobios, M.S. 18, 155-165.

FERnÁndeZ-López S. \& MELÉndez G. (1996). - Phylloceratina ammonoids in the Iberian basin during the Middle Jurassic: a model of biogeographical and taphonomic dispersal related to relative sea-level changes. - Palaeogeogr., Palaeoclimatol., Palaeoecol., 120 291-302.

FERnÁNDEZ-LóPEZ S. \& MELÉndez G. (2004). - Fossilization of ammonites and sedimentary events in deep environments of carbonate platform (highest Middle to lowest Upper Oxfordian, Iberian Range, Spain). - Riv. Ital. Paleontol. Stratigr., 110, 219-230

FERnÁndeZ-LóPez S. \& Mouterde R. (1994). - L'horizon à Gervillii (Bajocien inférieur) de Tendron (Cher, France). Taphonomie et populations d'ammonites. - Misc. Serv. Geol. Naz., 5, 117-159.

Fernández-López S. \& Mouterde R. (1997). - Observations taphonomiques et paléoécologiques sur 1'association d'ammonites de l'horizon à Gervillii (Bajocien inférieur) de Tendron (Cher, France). - Cah. Univ. Catho. Lyon, 10, 147-157

Fernández-López S., Meléndez G. \& Sequeiros L. (1985). - Le Dogger et le Malm de Sierra Palomera (Teruel). - Strata, 2, 142-151.

Fernández-López S., Henriques M.H.P. \& Duarte L.V. (2002). - Taphonomy of ammonite condensed associations. Jurassic examples from carbonate platforms of Iberia. - Abh. Geol. B.-A., 57, 423-430.

FÜRSICH F.T. \& OschmanN W. (1993). - Shell beds as tools in basin analysis: the Jurassic of Kachchh, western India Spain). - J. Geol Soc. London, 150, 169-185.

Fürsich F.T., Werner W., Schneider S. \& MÄUSER M. (2007). - Sedimentology, taphonomy, and palaeoecology of a laminated plattenkalk from the Kimmeridgian of the northern Franconian Alb (southern Germany). - Palaeogeogr., Palaeoclimatol., Palaeoecol., 243, 92-117.
GARCíA-Frank A. (2006). - Evolución biosedimentaria y secuencial del Jurásico Medio inferior en la Cuenca Ibérica (Sector NO). 529 p. - Tesis doctoral, Univ. Complutense Madrid, 2006

Gómez J.J. \& Fernández-López S. (1994). - Condensation processes in shallow platforms. - Sediment. Geol., 92, 147-159.

Gómez J.J. \& FERnÁNDEZ-LóPEZ S. R. (2004). - Las unidades litoestratigráficas del Jurásico medio de la Cordillera Ibérica. - Geogaceta, 35, 91-94.

Gómez J.J. \& FernÁndez-LóPez S.R. (2006). - The Iberian Middle Jurassic carbonate-platform system: Synthesis of the palaeogeographic elements of its eastern margin (Spain). - Palaeogeogr., Palaeoclimatol., Palaeoecol., 236, 190-205.

Hagdorn H. \& Mundlos R. (1983). - Aspekte der Taphonomie von Muschelkalk-Cephalopoden. Teil 1. Siphozerfall und Füllmechanismus. - N. Jb. Geol. Paläont. Abh., 166, 369-403.

Hernández A., Ramírez J.L., Olive A. \& Riba O. (1983). - Hoja 566 (26-22) Cella. - Mapa Geológico España, IGME, Madrid, 68 p.

JACKSON J.A. (1997). - Glossary of geology. - American Geological Institute, Alexandria, Virginia, $769 \mathrm{p}$

Kietzmann D.A. \& Palma R.M. (2009). - Tafofacies y biofacies de la formación Vaca Muerta en el sector surmendocino de la Cuenca Neuquina: implicancias paleoecológicas, sedimentológicas y estratigráficas. - Ameghiniana, 46, 321-343.

Maeda H. \& Seilacher A. (1996). - Ammonoid taphonomy. In: N.H. Landman, K. Tanabe \& R.A. Davis, Eds, Ammonoid paleobiology. - Plenum Press, New York, 543-578.

Maeda H., Mapes R.H. \& Mapes G. (2003). - Taphonomic features of a Lower Permian beached cephalopod assemblage from Central Texas. - Palaios, 18, 421-434.

Maeda H., Kumagae T., Matsuoka H. \& Yamazaki Y. (2010). - Taphonomy of large Canadoceras (Ammonoid) shells in the Upper Cretaceous series in South Sakhalin, Russia). - Paleont. Res., 14, 56-68.

Martire L. \& Pavia G. (1996). - Taphonomic analysis of Bajocian ammonites from NW France (Normandy, Poitou). - Georesearch Forum, 1-2, 305-316.

Meléndez G., Fernández-López S., Soria Llop C., Pérez Urresti I., Bello J., Delvene G., Comas-Rengifo M.J., Goy A., Clemente E. \& RodríGuez MorA M. (2002). - Yacimientos paleontológicos del Jurásico de la sierra de Albarracín (Rama Castellana de la Cordillera Ibérica): aspectos estratigráficos y patrimoniales. In: G. Meléndez \& E. PeÑalver, Eds., El patrimonio paleontológico de Teruel. - Instituto de Estudios Turolenses, Teruel, 81-136.

Meléndez G., Ramajo J. \& Martínez-Cotanda S. (2005). - El desarrollo de la capa de Arroyofrío (límite Calloviense-Oxfordiense) al sur de Zaragoza, entre Ricla y Aguilón: bioestratigrafía y facies. Geogaceta, 38, 3-6.

Meléndez G., Ramajo J., Bello J. \& Page K.N. (2007). - Callovian and the Callovian - Oxfordian transition sedimentary record in NE Iberian Chain: Taphonomic analysis and palaeogeography. J. Iberian Geol., 33,261-282.

Meléndez G., Atrops F., Bello J., Brochwicz-Lewinski W., D'arpa C., Fözy I., Pérez-Urresti I., Ramajo J. \& Sequeiros L. (2009). The Oxfordian ammonite genus Passendorferia BROCH WICZ-LEWINSKI and the Tethyan subfamily Passendorferiinae Meléndez: origin and palaeobiogeography. - Volumina Jurassica, 7, 113-134.

Metodiev L. \& Koleva-Rekalova E. (2005). - Preservational features of the upper Pliensbachian - lower Bajocian belemnite rostra from two clayey-limestone successions of the west Balkan Mts (Bulgaria). Taphonomic and sedimentological evidence. $-C . R$. Acad. Bulgare Sci., 58, 705-710.

Monaco P. (1999). - Computer database as a tool to investigate taphonomy and events in carbonate platform environments. - Palaeopelagos, 2, 105-122.

MonACo P. (2000). - Biological and physical agents of shell concentrations of Lithiotis facies enhanced by microstratigraphy and taphonomy, Early Jurassic, Trento area (northern Italy). - GeoResearch Forum, 6, 473-486.

Monaco P. \& Giannetti A. (2001). - Stratigrafia tafonomica nel Giurassico inferiore dei Calcari Grigi della piattaforma di Trento. - Atti Ticinensi Scienze della Terra, 42, 175-209. 
Monaco P. \& Giannetti A. (2002). - Three-dimensional burrow systems and taphofacies in shallowing-upward parasequences, Lower Jurassic Carbonate plarform (Calcari Grigi, Southern Alps, Italy). Facies, 47, 57-82.

Olóriz F., REOLID M. \& Rodríguez-Tovar F. (2002). - Fossil assemblages, lithofacies and taphofacies for interpreting depositional dy namics in epicontinental Oxfordian (Prebetic Zone, Betic Cordillera, southern Spain). - Palaeogeogr., Palaeoclimatol. Palaeoecol., 185, 53-75.

Olóriz F., REOLID M. \& RodríGUEZ-Tovar F. (2004). - Taphonomy of ammonite assemblages from the middle-upper Oxfordian (Transversarium?-Bifurcatus zones) in the Internal Prebetic (Betic Cordillera, southern Spain): taphonic populations and taphofacies to support ecostratigraphic interpretations.). - Riv. Ital. Paleontol. Stratigr., 110, 239-248.

OlóRIz F., REOLid M. \& Rodríguez-Tovar F. (2008). - Taphonomy of fossil macro-invertebrate assemblages as a tool for ecostratigraphic interpretation in Upper Jurassic shelf deposits (Prebetic Zone, southern Spain). - Geobios, 41, 31-42.

Paul C.R.C., Allison P.A. \& Brett C.E. (2008). - The occurrence and preservation of ammonites in the Blue Lias formation (lower Jurassic) of Devon and Dorset, England and their palaeoecological, sedimentological and diagenetic significance. Palaeogeogr., Palaeoclimatol., Palaeoecol., 270, 258-272.

PAVIA G. (1994). - Taphonomic remarks on d'Orbigny's type-Bajocian (Bayeux, west France). - Misc. Serv. Geol. Naz., 5, 93-111.

PAvia G. \& MARTiRe L. (1997). - The importance of taphonomic studies on biochronology: examples from the European Middle Jurassic. Cuad. Geol. Ibérica, 23, 153-181.

PAVIA G. \& MARTIRE L. (2009). - Indirect biostratigraphy in condensed successions: a case history from the Bajocian of Normandy (NW France). - Volumina Jurassica, 7, 67-76.

RAmajo Cordero J. (2006). - Evolución sedimentaria del Calloviense-Oxfordiense en el sector central de la Cordillera Ibérica (Rama Aragonesa). - Tesis doctoral, Univ. Zaragoza, 2005, $405 \mathrm{p}$.

Reboulet S., Giraud F. \& Proux O. (2005). - Ammonoid abundance variations related to changes in trophic conditions across the oceanic anoxic event 1d (Latest Albian, SE France). - Palaios, 20, 121-141.
Reboulet S., Mattioli E., Pittet B., Baudin F., Olivero D. \& Proux O. (2003). - Ammonoid and nannoplankton abundance in Valanginian (early Cretaceous) limestone-marl successions from the southeast France basin: carbonate dilution or productivity? - $P a$ laeogeogr., Palaeoclimatol., Palaeoecol., 201, 113-139.

REOLID PÉREZ M. (2005). - Dinámica eco-sedimentaria durante el Oxfordiense medio-Kimmeridgiense temprano en la Zona Prebética: interpretación ecoestratigráfica y secuencial. - Tesis doctoral, Univ. Granada, 2005, 254 p.

Reolid M., Gaillard C., Olóriz F. \& Rodríguez-Tovar F.J. (2005). - Microbial encrustations from the Middle Oxfordian-earliest Kimmeridgian lithofacies in the Prebetic Zone (Betic Cordillera, southern Spain): characterization, distribution and controlling factors. - Facies, 50, 529-543.

Reolid M., Nieto L.M. \& Rey J. (2010). - Taphonomy of cephalopod assemblages from Middle Jurassic hardgrounds of pelagic swells (South-Iberian palaeomargin, western Tethys). - Palaeogeogr., Palaeoclimatol., Palaeoecol., 292, 257-271.

SEILACHER A. (1971). - Preservational history of ceratite shells. - Palaeontology, 14, 16-21.

Seilacher A., Andalib F., Dietl G. \& Gocht H. (1976). - Preservational history of compressed Jurassic ammonites from southern Germany. - N. Jb. Geol. Paläont. Abh., 152, 303-356.

Shevyrev A.A. (2006). - The Cephalopod macrosystem: A historical review, the present state of knowledge, and unsolved problems: 3 Classification of Bactritoidea and Ammonoidea. - Paleontol. J., 40, 150-161.

Tintant H. (1984). - Autochtonie ou allochtonie chez les Céphalopodes. Mém. Géol. Univ. Dijon, 7 (1982), 257-271.

Tomasovych A. \& Schlögl J. (2008). - Analyzing variations in cephalopod abundances in shell concentrations: the combined effects of production and density-dependent cementation rates). - Palaios, 23, 648-666.

WANI R. (2003). - Taphofacies models for Upper Cretaceous ammonoids from the Kotanbetsu area, northwestern Hokkaido, Japan). - Palaeogeogr., Palaeoclimatol., Palaeoecol., 292, 257-271. 